\title{
Alpha cell function in type 1 diabetes
}

\author{
DAVID SIMON HUGHES, PARTH NARENDRAN
}

\begin{abstract}
Our understanding of the pathogenesis of type 1 diabetes mellitus has traditionally revolved around the insulin deficiency that follows pancreatic beta cell loss. However, there is an increasing appreciation of defects in other glucoregulatory cells in type 1 diabetes mellitus. Oversecretion of glucagon from pancreatic alpha cells is characteristic of type 1 diabetes mellitus, and modulating these glucagon levels reduces hyperglycaemia. This article reviews alpha cell function in type 1 diabetes mellitus. We examine how its function is controlled and compromised, and review studies that target alpha cell function. Finally, we explore potential approaches to modulating alpha cell function in type 1 diabetes mellitus.

Br J Diabetes Vasc Dis 2014; 14:45-51
\end{abstract}

Key words: alpha cell, glucagon, siabetes, type 1, islets of Langerhans, DPP-4, GLP-1, insulin

\section{Introduction}

Alpha cells comprise less than $1 \%$ of the pancreatic volume and normally about $30 \%$ of the pancreatic islets. They are defined immunohistochemically by the presence of glucagon staining, and secretion of glucagon is considered to be their primary role. The glucagon secreting alpha cell and insulin secreting beta cell share a common cell lineage, but differ in their terminal differentiation into their characteristic cell types. ${ }^{1}$

Alpha cells remind us of the enormous contribution that students make to scientific discovery. In 1869, Paul Langerhans identified an island of clear cells in the pancreas whilst still a 22 year old medical student. These were later named the islets of Langerhans and are now known to contain alpha cells. In 1907 another medical student, Michael Lane, discovered there were two distinct cell types in the islets, which he went on to term the 'alpha' and 'beta' cell. ${ }^{2}$ Charles Best, whilst working as a

Centre of Endocrinology, Diabetes and Metabolism, Institute of Biomedical Research, University of Birmingham, Edgbaston, Birmingham, B15 2TT, UK

Address for correspondence: Dr Parth Narendran Centre of Endocrinology, Diabetes And Metabolism, Institute of Biomedical Research, University of Birmingham, Edgbaston,

Birmingham, B15 2TT, UK.

Tel: +44 (0)1213714407

E-mail: p.narendran@bham.ac.uk

http://dx.doi.org/10.15277/bjdvd.2014.014

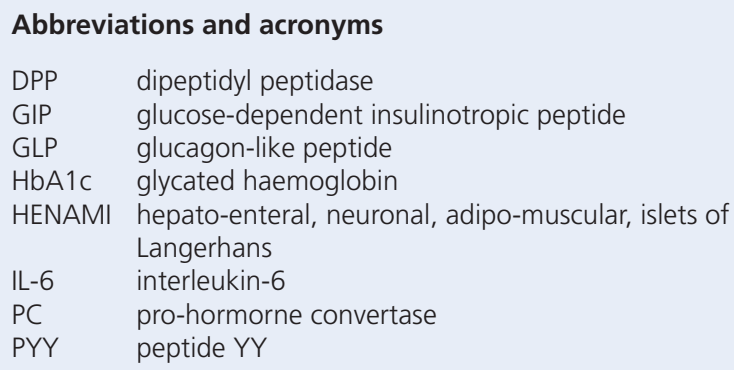

medical student for Dr Fredrick Banting, noted that the injection of crude canine pancreatic extracts to diabetic dogs resulted in an early rise in blood glucose, before subsequent hypoglycaemia. Finally, in 1923 Charles Kimball, a biochemistry student, isolated a substance from the alpha cell and named it "glucagon". ${ }^{3}$ Despite such a significant discovery, he never received his PhD from the University of Rochester.

\section{Physiology of alpha cells} Glucagon and glucose regulation

Glucagon increases blood glucose. It does so through targeting a $62 \mathrm{kDa} \mathrm{G}$-protein coupled receptor that is expressed predominantly in the liver and kidney, and to a lesser extent in adipose tissue, spleen, heart and gastro-intestinal tract. ${ }^{4}$ Stimulation of the glucagon receptor results in glycogenolysis and gluconeogenesis, and suppression of glycogenesis and glycolysis. Both glycogenolysis of the liver and muscle glycogen stores and gluconeogenesis of non-carbohydrate stores release glucose (Figure 1).

\section{Molecular biology of glucagon}

The proglucagon gene was identified in 1983, four years after the insulin gene was sequenced. The proglucagon gene encodes for glucagon and GLP-1 and 2 respectively (Figure 2). The proglucagon gene is expressed by pancreatic alpha cells, intestinal L-cells as well as some neuronal cells. ${ }^{5,6}$ These cells express

Figure 1. Glycogen and glucose homoeostasis

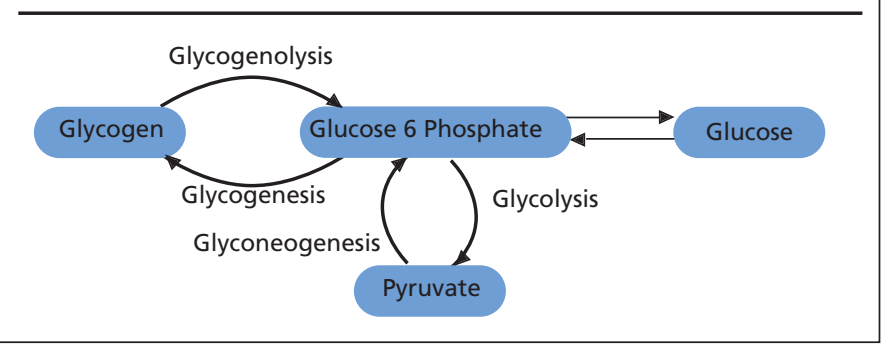


Figure 2. Post-translational processing of the proglucagon peptide. The proglucagon peptide is processed by PC2 in the pancreas to generate glucagon, and by $P C 1 / 3$ in the gut and nervous system to generate GLP-1 and GLP-2.

Grop
Brain \& Intestine

different isoforms of the enzyme pro-hormorne convertase (PC) and therefore differentially processes the gene product. PC $1 / 3$ is predominantly expressed in the intestinal L-cells and cleaves proglucagon to GLP-1 and GLP-2. PC2 is predominantly expressed in pancreatic alpha cells and the glucagon secreting enteroendocrine cells of the stomach, and cleaves proglucagon to glucagon. ${ }^{7}$

The proglucagon peptide is processed by $\mathrm{PC} 2$ in the pancreas to generate glucagon, and by $P C 1 / 3$ in the gut and nervous system to generate GLP-1 and GLP-2.

\section{Control of glucagon secretion}

In health, a rise in blood glucose activates both a glucose dependent and independent inhibition of glucagon secretion from alpha cells. These pathways control blood glucose and regulate the storage and utilisation of energy.

Support for a direct glucose dependent pathway for modulating alpha cell-glucagon secretion comes from observations

Figure 3. The HENAMI - (hepato-enteral, neuronal, adipo-muscular, islet) hormonal network for the control of glucagon secretion

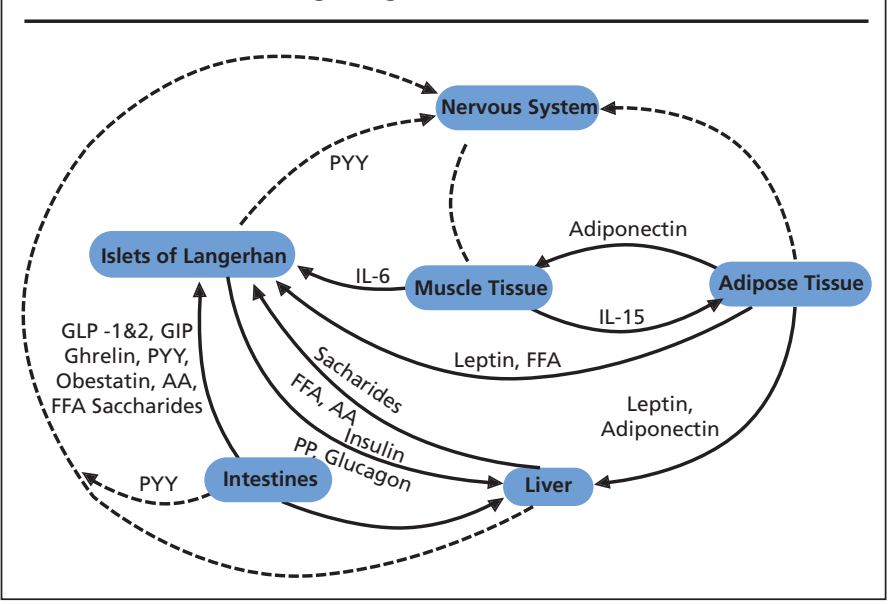

Figure 4. Cells of the islets of Langerhans

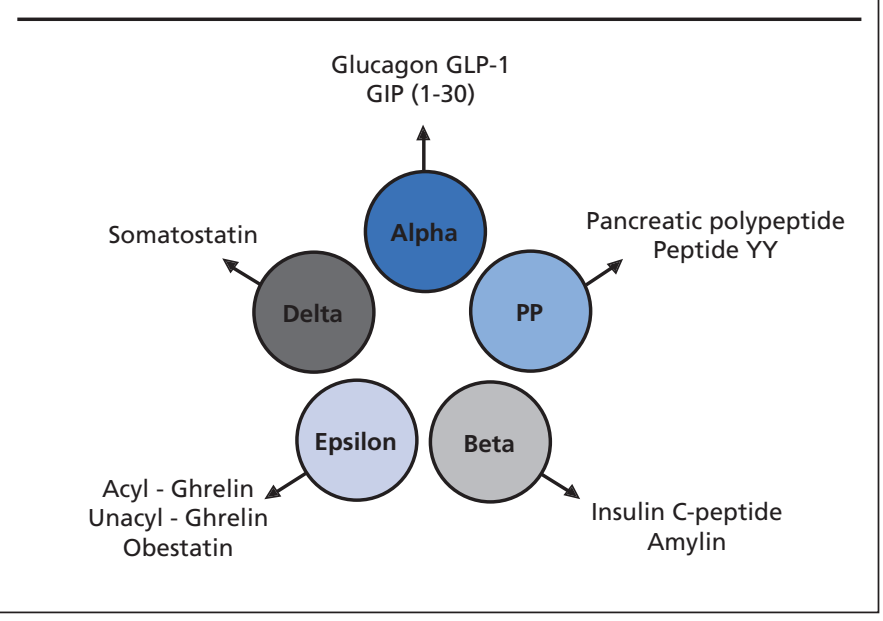

that these cells express ATP regulated potassium channels and glucokinase - both required for glucose sensing. ${ }^{8}$ The exact pathways through which glucose modulates glucagon secretion remain to be elucidated. However isolated alpha cells are able to alter their metabolism in response to changes in glucose, and this is associated with changes in cell membrane potential, calcium influx, and exocytosis of glucagon containing secretory granules. 9,10

The glucose independent pathway for modulating glucagon secretion involves a network of the liver, intestine, nervous, muscular and adipose tissue. We term this the HENAMI network (Figure 3). The islets of Langerhans are a key part of this network and are composed of five distinct types of endocrine cells (see Figure 4). ${ }^{11-13}$

Within the islets, beta cells exert a major paracrine effect (Figure 5) which mediates through insulin, zinc and / or amylin. Insulin directly suppresses glucagon secretion as do amylin and zinc, both co-secreted with insulin. ${ }^{14}$

Alpha cells express somatostatin receptors. Somatostatin is

Figure 5. Paracrine and endocrine control of glucagon secretion by the alpha cell

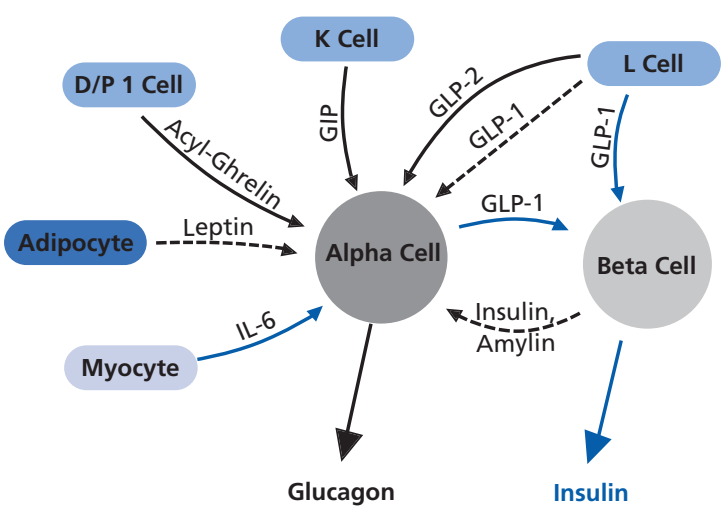


an inhibitory hormone on somatotrophs and beta cells, and decreases glucagon secretion. ${ }^{15}$

Intestinal L cells secrete GLP-1. GLP-1 inhibits glucagon release from the alpha cells and potentiates glucose induced insulin secretion. ${ }^{16}$ Intestinal K cells secrete GIP, which stimulates glucagon release and also protects beta cells from apoptosis. ${ }^{17}$ In healthy humans, GIP administration results in dose-dependent glucagon secretion. ${ }^{18}$

The adipocyte hormone leptin inhibits glucagon release and is associated with satiety. ${ }^{19}$ Leptin is closely related to IL- 6 that is released from muscle tissue in response to vigorous exercise. ${ }^{20}$ IL-6 can also stimulate alpha cells to secrete low levels of GLP-1, which stimulates beta cell secretion of insulin and has antiapoptotic effects on the beta cell. ${ }^{21}$ The islets are also heavily innervated by both sympathetic and parasympathetic nerves that are capable of modulating alpha cell function. ${ }^{22}$ These effects are mediated via catecholamines, but also through neuropeptides such as neuropeptide $\mathrm{Y}$.

\section{Type 1 diabetes mellitus and the alpha cell}

Recent onset of type 1 diabetes mellitus is histo-pathologically characterised by the lymphocytic infiltration of the islets of Langerhans. ${ }^{23}$ Histological analysis of pancreata from individuals newly diagnosed with type 1 diabetes mellitus shows specific beta cell loss, with preservation of alpha and other islet cells. Some reports also suggest mild alpha cell hyperplasia at the time of diagnosis. ${ }^{24}$

A primary role for glucagon in the pathology of type 1 diabetes mellitus has been intimated where disruption of glucagon signalling has resulted in protection from diabetes in glucagon receptor knockout mice. ${ }^{25}$ In streptozotocin-induced diabetes the severity of the condition is proportional to the number of surviving beta cells and studies have shown that essentially blocking glucagon action improves glycaemic control, thus the mice are protected from diabetes. This is consistent with previous studies of glucagon receptor modulation. $25-28$

The loss of beta cells in type 1 diabetes mellitus and the resulting loss of insulin mediated suppression of glucagon secretion may be expected to result in persistently elevated levels of glucagon. This has been reported in many but not all studies.29-31 Whilst absolute levels of glucagon may not consistently be elevated, it is clear that these glucagon levels are higher than would be expected for the hyperglycaemia associated with type 1 diabetes mellitus. Furthermore, alpha cell responses to both rising and falling levels of glucose appear compromised in type 1 diabetes mellitus. In health, an increase in glucose, for example following a meal, results in an increase in insulin secretion and either a decrease or no change in glucagon. In type 1 diabetes mellitus, a meal stimulus results in a paradoxical increase in glucagon secretion as demonstrated in children with type 1 diabetes mellitus. ${ }^{32}$ The inappropriate increase in meal stimulated glucagon appears to be present at the time of diagnosis, and continues to deteriorate in the following year. It is not clear how longer duration type 1 diabetes mellitus or the presence of complications such as autonomic neuropathy modulates alpha cell behaviour.
The reasons for an inappropriate increase in glucagon in type 1 diabetes mellitus are likely to be multi-factorial. Some studies have reported normal glucagon suppression to an intravenous glucose challenge, whilst an oral challenge results in an inappropriate increase. ${ }^{33-35}$ Incretin mediated control of glucagon secretion may therefore be modulated by type 1 diabetes mellitus. It has also been proposed that alpha cells need to sense a rise in insulin to decrease their glucagon secretion, and this rise will not be present in type 1 diabetes mellitus. ${ }^{36}$ However studies from type 2 diabetes mellitus suggest the impaired ability of the alpha cell to decrease glucagon secretion in the setting of hyperglycaemia may relate more to defects in the ability of the alpha cell to detect and respond to glucose than the decline in insulin secretion. ${ }^{37}$ This is supported by studies of type 1 diabetes mellitus patients early in the natural history of their disease where there are defects in stimulated insulin secretion but not in glucose levels. These patients demonstrate a lack of suppression of glucagon rather than the overt rise detectable in patients later in their natural history. ${ }^{38}$ Therefore defects in both the glucose dependent and independent pathways controlling glucagon secretion may contribute to the hyperglycaemia of type 1 diabetes mellitus.

In health, falling glucose triggers glucagon secretion, a phenomenon that is often absent in type 1 diabetes mellitus. ${ }^{39,40}$ Furthermore, the greater the loss of beta cell function, the more blunted the glucagon increase with hypoglycaemia. ${ }^{41,42}$ This blunted response increases the risk of hypoglycaemia in patients with type 1 diabetes mellitus.

\section{Currently available drugs that target alpha cell function The GLP-1 pathway}

GLP-1 treatment of pancreatic alpha cells reduces glucagon secretion..$^{43}$ GLP-1 stimulation of beta cells, and the paracrine effects of the secreted insulin on adjacent alpha cells, also contributes to this reduction in glucagon secretion. Thus, drugs that target the incretin pathway such as GLP-1 agonists and DPP-4 inhibitors exert some of their glycaemic effects through a reduction in endogenous glucagon. These drugs have now established themselves as important agents for the therapy of type 2 diabetes mellitus.

Exploratory trials of the use of GLP-1 modulation in type 1 diabetes mellitus suggest glycaemic benefit (see Table 1).44-46 Varanasi et al showed that the administration of a GLP-1 analogue in individuals with well controlled type 1 diabetes mellitus improved mean fasting glucose and decreased glycaemic excursions. These improvements in glycaemic control were evident after one week of treatment and persisted for the 24-week trial. Kielgast et al showed a reduction in $\mathrm{HbA} 1 \mathrm{c}$ even in the absence of detectable C-peptide, suggesting that GLP-1 receptor agonism exerts an insulin-independent inhibitory effect on alpha cells. Both these trials showed a reduction in insulin requirements without an increase in hypoglycaemia. There was evidence of weight loss in both studies. Although large trials are under way, GLP-1 analogues are currently unlicensed for use in type 1 diabetes mellitus. 
Table 1 Trials of GLP-1 modulation in type 1 diabetes

\begin{tabular}{|c|c|c|c|c|c|c|}
\hline Study & $\begin{array}{l}\text { Number of } \\
\text { participants }\end{array}$ & Study design & $\begin{array}{l}\text { Duration of } \\
\text { intervention }\end{array}$ & Intervention & HbA1c(\%) effect & $\begin{array}{l}\text { Meal stimulated } \\
\text { glucagon effect }\end{array}$ \\
\hline $\begin{array}{l}\text { Varanasi } \\
2011^{44}\end{array}$ & 8 subjects & $\begin{array}{l}\text { Open-labelled, } \\
\text { cohort trial }\end{array}$ & 24 weeks & $\begin{array}{l}\text { Liraglutide } \\
\text { variable dose }\end{array}$ & $\begin{array}{l}\text { Baseline vs } 24 \text { weeks: } \\
6.5 \text { vs } 6.1, p<0.05\end{array}$ & $\mathrm{~N} / \mathrm{A}$ \\
\hline $\begin{array}{l}\text { Kielgast } \\
2011^{45}\end{array}$ & 29 subjects & $\begin{array}{l}\text { Open-labelled, } \\
\text { cohort trial }\end{array}$ & 4 weeks & $\begin{array}{l}\text { Liraglutide } \\
1.2 \mathrm{mg} \text { od }\end{array}$ & $\begin{array}{l}\text { Baseline vs } 4 \text { weeks: } \\
\text { C-peptide +ve on liraglutide } \\
(n=10) 6.6+/-0.3 \text { vs } 6.4+/-0.3 \text {, } \\
p<0.05 ; C \text {-peptide }- \text { ve on } \\
\text { liraglutide }(n=9) 7.5+/-0.2 \text { vs } \\
7.0+/-0.1, p<0.05 ; C \text {-peptide } \\
\text {-ve not on liraglutide }(n=10) \\
7.1+/-0.3 \text { vs } 6.9+/-0.2, p>0.05\end{array}$ & $\mathrm{~N} / \mathrm{A}$ \\
\hline $\begin{array}{l}\text { Raman } \\
2010^{46}\end{array}$ & 8 subjects & $\begin{array}{l}\text { Double-blinded, } \\
\text { randomized, placebo } \\
\text { controlled trial. }\end{array}$ & Single dose & $\begin{array}{l}\text { Exenatide } 1.25 \mu \mathrm{g}- \\
2.5 \mu \mathrm{g} \text { or placebo }\end{array}$ & $\mathrm{N} / \mathrm{A}$ & $\begin{array}{l}\text { Exenatide vs } \\
\text { placebo } p>0.05\end{array}$ \\
\hline
\end{tabular}

Table 2 Trials of DPP-4 inhibitors in type 1 diabetes

\begin{tabular}{|c|c|c|c|c|c|c|}
\hline Study & $\begin{array}{l}\text { Number of } \\
\text { participants }\end{array}$ & Study design & $\begin{array}{l}\text { Duration of } \\
\text { intervention }\end{array}$ & Intervention & HbA1c(\%) effect & $\begin{array}{l}\text { Meal stimulated } \\
\text { glucagon effect }\end{array}$ \\
\hline $\begin{array}{l}\text { Garg } \\
2012^{47}\end{array}$ & 125 subjects & $\begin{array}{l}\text { Double-blind, } \\
\text { randomized } \\
\text { placebo-controlled } \\
\text { parallel trial. }\end{array}$ & 16 weeks & $\begin{array}{l}\text { Sitagliptin } 100 \mathrm{mg} \text { od } \\
\text { or placebo. }\end{array}$ & $\begin{array}{l}\text { Change from baseline: } \\
\text { sitagliptin } 100 \mathrm{mg} \text { vs placebo; } \\
-0.07+/-0.7 \text { vs }-0.12+/-0.75 \\
p>0.05\end{array}$ & $\begin{array}{l}4 \mathrm{hrs} \\
\text { AUC (pg/ml.min) } \\
\text { sitagliptin vs } \\
\text { placebo: } 84.7 \pm \\
23.6 \text { vs } 84.9 \pm \\
35.3, \quad p>0.05\end{array}$ \\
\hline $\begin{array}{l}\text { Ellis } \\
2011^{49}\end{array}$ & 20 subjects & $\begin{array}{l}\text { Double-blind, } \\
\text { randomized, } \\
\text { placebo-controlled } \\
\text { crossover trial. }\end{array}$ & 4 weeks & $\begin{array}{l}\text { Sitagliptin } 100 \mathrm{mg} \text { od } \\
\text { or placebo. }\end{array}$ & $\begin{array}{l}\text { Difference between } 4 \text { weeks: } \\
\text { sitagliptin vs placebo; } \\
-0.27+/-0.11 \%, p<0.05\end{array}$ & N/A \\
\hline
\end{tabular}

\section{DPP-4 inhibitors}

DPP-4 is an enzyme that degrades endogenous GLP-1, and inhibiting DPP-4 potentiates the incretin pathways. These drugs are well established for therapy in type 2 diabetes mellitus but are currently unlicensed for type 1 diabetes mellitus. However, recent studies show promise for this class of drug in treating type 1 diabetes mellitus. A four week study of vildagliptin treatment in 28 participants with type 1 diabetes mellitus successfully reduced their meal stimulated glucagon levels. A 16-week intervention study of sitagliptin in 125 participants with type 1 diabetes mellitus showed not only improvement in glucagon levels, but also a reduction in $\mathrm{HbA} 1 \mathrm{c}$ (see Table 2). ${ }^{47-50}$ Whilst larger trials are awaited, this class of therapy remains unlicensed for type 1 diabetes mellitus.

\section{Amylin}

Pramlintide is an amylin analogue licensed in the USA as an adjunct therapy to insulin in type 1 diabetes mellitus and type 2 diabetes mellitus. Amylin is co-secreted with insulin from beta cells, and is therefore absent in long standing type 1 diabetes mellitus. In a randomised controlled trial pramlintide $60 \mathrm{~g}$ given three or four times a day for a year decreased $\mathrm{HbA} 1 \mathrm{c}$ by $\sim 0.3 \%$, but another randomised controlled trial was unable to detect any benefit at 6 months (Table 3). Pramlintide can significantly decrease post-meal glucagon levels in type 1 diabetes mellitus and trials have also shown that pramlintide reduces glucose variability by delaying gastric emptying. ${ }^{51-55}$ 
Table 3 Trials of the amylin analogue pramlintide in type 1 diabetes mellitus

\begin{tabular}{|c|c|c|c|c|c|c|}
\hline Study & $\begin{array}{l}\text { Number of } \\
\text { participants }\end{array}$ & Study design & $\begin{array}{l}\text { Duration of } \\
\text { intervention }\end{array}$ & Intervention & HbA1c(\%) effect & $\begin{array}{l}\text { Meal stimulated } \\
\text { glucagon effect }\end{array}$ \\
\hline $\begin{array}{l}\text { Chase } \\
2009^{51}\end{array}$ & 9 subjects & $\begin{array}{l}\text { Single blinded, } \\
\text { randomised } \\
\text { placebo controlled, } \\
\text { crossover trial. }\end{array}$ & Single dose & $\begin{array}{l}\text { Pramlintide } 15 \mu \mathrm{g} \text { or } \\
\text { pramlintide } 30 \mu \mathrm{g} \\
\text { or placebo }\end{array}$ & $\mathrm{N} / \mathrm{A}$ & $\begin{array}{l}\text { 3hr AUC } \\
\text { (pg/ml.hr) } \\
\text { pramlintide } \\
15 \mathrm{mcg} \text { vs } \\
\text { pramlintide } \\
30 \mathrm{mcg} \text { vs } \\
\text { placebo: } 4+/-7 \text { vs } \\
5+/-7 \text { vs } 35+/-9\end{array}$ \\
\hline $\begin{array}{l}\text { Edelman } \\
2006^{52}\end{array}$ & 230 subjects & $\begin{array}{l}\text { Double-blinded, } \\
\text { randomized, } \\
\text { placebo controlled } \\
\text { trial. }\end{array}$ & 29 weeks & $\begin{array}{l}\text { Pramlintide } 30-60 \mu \mathrm{g} \\
\text { tds or placebo }\end{array}$ & $\begin{array}{l}\text { Change from baseline: } \\
\text { pramlintide vs placebo; } \\
-0.5 \% \text { vs }-0.5 \%, p>0.05\end{array}$ & N/A \\
\hline $\begin{array}{l}\text { Ratner } \\
2004^{53}\end{array}$ & 304 subjects & $\begin{array}{l}\text { Double-blinded, } \\
\text { randomized, } \\
\text { placebo controlled } \\
\text { trial. }\end{array}$ & 52 weeks & $\begin{array}{l}\text { Pramlintide } 60 \mu \mathrm{g} \text { tds } \\
\text { or pramlintide } 60 \mu \mathrm{g} \\
\text { od or placebo }\end{array}$ & $\begin{array}{l}\text { Change from baseline: } \\
\text { pramlintide tds vs } \\
\text { pramlintide od vs placebo; } \\
-0.29 \% \text { vs }-0.34 \% \text { vs } \\
-0.04 \%, p<0.05\end{array}$ & $\mathrm{~N} / \mathrm{A}$ \\
\hline $\begin{array}{l}\text { Levetan } \\
2003^{54}\end{array}$ & 18 subjects & $\begin{array}{l}\text { Open-labelled, } \\
\text { cohort trial. }\end{array}$ & 4 weeks & Pramlintide $30 \mu \mathrm{g}$ tds & N/A & $\begin{array}{l}\text { 3hr AUC } \\
\text { (pg/ml.hr) } \\
\text { baseline vs } 4 \\
\text { weeks: } 55+/-44 \text { vs } \\
\text { 7+/-38, p<0.05 }\end{array}$ \\
\hline $\begin{array}{l}\text { Whitehouse } \\
2002^{55}\end{array}$ & 342 subjects & $\begin{array}{l}\text { Double-blinded, } \\
\text { randomized, } \\
\text { placebo controlled } \\
\text { study }\end{array}$ & 52 weeks & $\begin{array}{l}\text { Pramlintide } 30-60 \mu \mathrm{g} \\
\text { od or placebo }\end{array}$ & $\begin{array}{l}\text { Change from baseline: } \\
\text { pramlintide vs placebo; } \\
-0.39 \% \text { vs }-0.12 \%, p<0.01\end{array}$ & N/A \\
\hline
\end{tabular}

\section{Novel drugs that target the glucagon pathway and alpha cell function}

An exciting potential for modulating the glucagon pathway lies in therapies that act directly on glucagon receptor signalling. As previously described, disruption of glucagon signalling ameliorates the hyperglycaemia of insulin deficient diabetes in animal studies. It was originally shown by Peter Flatt in 1979 that administration of glucagon antibodies modulated glucose levels ${ }^{56}$ - another first for a student - and more recently administration of glucagon receptor blocking antibodies to nondiabetic monkeys reduced blood glucose level in a dose dependent manner. ${ }^{57}$ The antibody was also given in higher doses to ob/ob mice and was successful in suppressing their hyperglycaemia. ${ }^{58}$ Early clinical trials in patients with type 2 diabetes mellitus show promise. ${ }^{59,60}$ Therefore therapies that modulate glucagon receptor signalling could potentially be used to treat the hyperglycaemia of type 1 diabetes mellitus. Potential limitations to this approach are early findings from studies in rodents that glucagon receptor modulation is associated with islet hyperplasia and disturbance in lipid metabolism in rodent studies, ${ }^{61}$ clearly issues that need further investigation.

Novel dual GLP-1/glucagon receptor and GLP-1/GIP receptor targeted peptides have been shown to treat hyperglycaemia in mice. ${ }^{62-64}$ In animal studies, circulating glucagon is decreased following therapy with ghrelin antagonists, and with leptin ago- nists. ${ }^{65,66}$ These therefore have therapeutic potential, and the leptin analogue metreleptin has now entered phase 1 clinical trials in patients with type 1 diabetes mellitus. ${ }^{67}$

A group of novel drugs that target the GPR119 receptor have shown promise in protecting mouse alpha and beta cells from streptozotocin-induced apoptosis ${ }^{68}$ and may therefore improve glycaemic control through preservation of these cells.

Tocilizumab, an IL-6 receptor monoclonal antibody, improved glycaemic control when given for the therapy of rheumatoid arthritis in patients with type 2 diabetes mellitus. ${ }^{69}$ Acute changes in IL-6 may act through increasing gut expression of GLP-1. Thus, there may be future scope in using the IL-6 receptor in regulating alpha cell secretion of glucagon and improving glycaemic variability.

\section{Conclusion}

Type 1 diabetes mellitus is a chronic autoimmune disease associated with a significant risk of long-term vascular complications. The risk of these complications is reduced by good glucose control. Functioning alpha cells as well as functioning beta cells are key to glycaemic homeostasis. The loss of beta cell function in type 1 diabetes mellitus results in unrestrained hyperglucagonaemia and thus to hyperglycaemia.

There are significant aspects of glucagon physiology that remain to be understood. In particular, the natural history of alpha cell function in type 1 diabetes mellitus needs to be fully eluci- 


\section{Key messages}

- Glucagon secretion is controlled by glucose plus a 'network' of hormones, and plays a critical role in the regulation of blood glucose

- GLP-1 agonists, DPP-4 inhibitors and amylin analogues modulate glucagon levels and have therapeutic potential in type 1 diabetes mellitus

- Novel agents are in development that directly influence glucagon receptor signalling.

dated. Meanwhile, a number of agents that modulate alpha cell function show therapeutic promise for type 1 diabetes mellitus. Currently, DPP-4 inhibitors and GLP-1 agonists utilised in type 2 diabetes mellitus may improve glycaemia in type 1 diabetes mellitus. They require large clinical trials to confirm safety and efficacy to examine their potential for routine clinical use.

\section{Conflict of interest None \\ Funding sources None}

Contributions DSH performed the literature search and wrote most of the article. PN reviewed and redrafted the article and supervised DSH.

Acknowledgements We thank Prof Patrik Rorsman and Dr Reshma Ramracheya at Oxford University for their invaluable help in putting this article together.

\section{References}

1. Doyle MJ, Loomis ZL, Sussel L. Nkx2.2-repressor activity is sufficient to specify alpha-cells and a small number of beta-cells in the pancreatic islet. Development 2007;134:515-23. http://dx.doi.org/10.1242/dev.02763

2. Lane M. The cytological characters of the areas of Langerhans. Am J Anat 1907;7:409-22. http://dx.doi.org/10.1002/aja.1000070304

3. Kimball CP, Murlin JR. Aqueous extracts of pancreas. J Biol Chem 1923;58:337-48.

4. Dunphy JL, Taylor RG, Fuller PJ. Tissue distribution of rat glucagon receptor and GLP-1 receptor gene expression. Mol Cell Endocrinol 1998;141:179-86. http://dx.doi.org/10.1016/S0303-7207(98)00096-3

5. Tucker JD, Dhanvantari S, Brubaker PL. Proglucagon processing in islet and intestinal cell lines. Regul Pept 1996;62:29-35. http://dx.doi.org/10.1016/0167-0115(95)00167-0

6. Llewellyn-Smith IJ, Reimann F, Gribble FM, et al. Preproglucagon neurons project widely to autonomic control areas in the mouse brain. Neuroscience 2011;180:111-21. http://dx.doi.org/10.1016/j.neuroscience.2011.02.023

7. Nie $Y$, Nakashima M, Brubaker PL, et al. Regulation of pancreatic PC1 and PC2 associated with increased glucagon-like peptide 1 in diabetic rats. J Clin Invest 2000;105:955-65. http://dx.doi.org/10.1172/JCI7456

8. Vieira E, Salehi a, Gylfe E. Glucose inhibits glucagon secretion by a direct effect on mouse pancreatic alpha cells. Diabetologia 2007;50:370-9. http://dx.doi.org/10.1007/s00125-006-0511-1

9. Rorsman P, Salehi SA, Abdulkader F, et al. K(ATP)-channels and glucoseregulated glucagon secretion. Trends Endocrinol Metab 2008;19:277-84. http://dx.doi.org/10.1016/j.tem.2008.07.003

10. Quesada I, Tudurí E, Ripoll C, et al. Physiology of the pancreatic alphacell and glucagon secretion: role in glucose homeostasis and diabetes. $J$ Endocrinol 2008;199:5-19. http://dx. doi.org/10.1677/JOE-08-0290

11. Ekblad E, Sundler F. Distribution of pancreatic polypeptide and peptide YY. Peptides 2002;23:251-61. http://dx.doi.org/10.1016/S0196-9781(01)00601-5

12. Andralojc KM, Mercalli A, Nowak KW, et al. Ghrelin-producing epsilon cells in the developing and adult human pancreas. Diabetologia 2009;52:486-93. http://dx.doi.org/10.1007/s00125-008-1238-y
13. Whalley NM, Pritchard LE, Smith DM, et al. Processing of proglucagon to GLP-1 in pancreatic \{alpha\}-cells: is this a paracrine mechanism enabling GLP-1 to act on \{beta\}-cells? J Endocrinol 2011;211:99-106. http://dx.doi.org/10.1530/JOE-11-0094

14. Gromada J, Franklin I, Wollheim CB. Alpha-cells of the endocrine pancreas: 35 years of research but the enigma remains. Endocr Rev 2007;28:84-116. http://dx. doi.org/10.1210/er.2006-0007

15. Kumar U, Sasi R, Suresh S, et al. Subtype-selective expression of the five somatostatin receptors (hSSTR1-5) in human pancreatic islet cells: a quantitative double-label immunohistochemical analysis. Diabetes 1999; 48:77-85. http://dx.doi.org/10.2337/diabetes.48.1.77

16. Meier JJ, Nauck MA. Glucagon-like peptide 1(GLP-1) in biology and pathology. Diabetes Metab Res Rev 2005;21:91-117. http://dx.doi.org/10.1002/dmrr.538

17. Parker HE, Habib AM, Rogers GJ, et al. Nutrient-dependent secretion of glucose-dependent insulinotropic polypeptide from primary murine $\mathrm{K}$ cells. Diabetologia 2009;52:289-98. http://dx. doi.org/10.1007/s00125-008-1202-x

18. Meier JJ, Gallwitz B, Siepmann N, et al. Gastric inhibitory polypeptide (GIP) dose-dependently stimulates glucagon secretion in healthy human subjects at euglycaemia. Diabetologia 2003;46:798-801. http://dx.doi.org/10.1007/s00125-003-1103-y

19. Tudurí E, Marroquí L, Soriano S, et al. Inhibitory effects of leptin on pancreatic alpha-cell function. Diabetes 2009;58:1616-24. http://dx.doi.org/10.2337/db08-1787

20. Pedersen BK, Febbraio MA. Muscle as an endocrine organ: focus on muscle-derived interleukin-6. Physiol Rev 2008;88:1379-406. http://dx.doi.org/10.1152/physrev.90100.2007

21. Ellingsgaard $H$, Hauselmann I, Schuler B, et al. Interleukin- 6 enhances insulin secretion by increasing glucagon-like peptide-1 secretion from $L$ cells and alpha cells. Nat Med 2011;17:1481-9. http://dx.doi.org/10.1038/nm.2513

22. Ahrén B. Autonomic regulation of islet hormone secretion--implications for health and disease. Diabetologia 2000;43:393-410. http://dx.doi.org/10.1007/s001250051322

23. Atkinson MA, Eisenbarth GS. Type 1 diabetes: new perspectives on disease pathogenesis and treatment. Lancet 2001;358:221-9. http://dx.doi.org/10.1016/S0140-6736(01)05415-0

24. Thorel F, Népote $V$, Avril I, et al. Conversion of adult pancreatic alphacells to beta-cells after extreme beta-cell loss. Nature 2010;464:1149-54. http://dx.doi.org/10.1038/nature08894

25. Lee $Y$, Wang $M-Y, D u X Q$, et al. Glucagon receptor knockout prevents insulin-deficient type 1 diabetes in mice. Diabetes 2011;60:391-7. http://dx.doi.org/10.2337/db10-0426

26. Gelling RW, Du XQ, Dichmann DS, et al. Lower blood glucose, hyperglucagonemia, and pancreatic alpha cell hyperplasia in glucagon receptor knockout mice. Proc Natl Acad Sci USA 2003:100:1438-43. http://dx.doi.org/10.1073/pnas.0237106100

27. Parker JC, Andrews KM, Allen MR, et al. Glycemic control in mice with targeted disruption of the glucagon receptor gene. Biochem Biophys Res Commun 2002;290:839-43. http://dx.doi.org/10.1006/bbrc.2001.6265

28. Brand CL, Rolin B, Jørgensen PN, et al. Immunoneutralization of endogenous glucagon with monoclonal glucagon antibody normalizes hyperglycaemia in moderately streptozotocin-diabetic rats. Diabetologia 1994;37:985-93. http://dx.doi.org/10.1007/BF00400461

29. Raskin P, Unger RH. Effect of insulin therapy on the profiles of plasma immunoreactive glucagon in juvenile-type and adult-type diabetics. Diabetes 1978;27:411-19. http://dx.doi.org/10.2337/diab.27.4.411

30. Brown RJ, Sinaii N, Rother KI. Too much glucagon, too little insulin: time course of pancreatic islet dysfunction in new-onset type 1 diabetes. Diabetes Care 2008;31:1403-04. http://dx. doi.org/10.2337/dc08-0575

31. Cooperberg BA, Cryer PE. Beta-cell-mediated signaling predominates over direct alpha-cell signaling in the regulation of glucagon secretion in humans. Diabetes Care 2009;32:2275-80. http://dx.doi.org/10.2337/ dc09-0798

32. Pörksen S, Nielsen LB, Kaas A, et al. Meal-stimulated glucagon release is associated with postprandial blood glucose level and does not interfere with glycemic control in children and adolescents with new-onset type 1 diabetes. J Clin Endocrinol Metab 2007:92:2910-16. http://dx.doi.org/10.1210/jc.2007-0244

33. Lindgren $\mathrm{O}$, Carr RD, Deacon CF, et al. Incretin hormone and insulin responses to oral versus intravenous lipid administration in humans. J Clin En- 
docrinol Metab 2011;96:2519-24. http://dx.doi.org/10.1210/jc.2011-0266

34. Meier JJ, Deacon CF, Schmidt WE, et al. Suppression of glucagon secretion is lower after oral glucose administration than during intravenous glucose administration in human subjects. Diabetologia 2007;50:80613. http://dx.doi.org/10.1007/s00125-007-0598-z

35. Hare KJ, Vilsbøøll T, Holst JJ, et al. Inappropriate glucagon response after oral compared with isoglycemic intravenous glucose administration in patients with type 1 diabetes. Am J Physiol Endocrinol Metab 2010;298:E832-7. http://dx.doi.org/10.1152/ajpendo.00700.2009

36. Cryer PE. Minireview: Glucagon in the pathogenesis of hypoglycemia and hyperglycemia in diabetes. Endocrinology 2012;153:1039-48. http://dx.doi.org/10.1210/en.2011-1499

37. Abdul-Ghani M, DeFronzo RA. Fasting hyperglycemia impairs glucose- but not insulin-mediated suppression of glucagon secretion. J Clin Endocrinol Metab 2007;92:1778-84. http://dx.doi.org/10.1210/jc.2006-1515

38. Greenbaum CJ, Prigeon RL, D'Alessio DA. Impaired beta-cell function, incretin effect, and glucagon suppression in patients with type 1 diabetes who have normal fasting glucose. Diabetes 2002;51:951-7. http://dx.doi.org/10.2337/diabetes.51.4.951

39. Siafarikas A, Johnston RJ, Bulsara MK, et al. Early loss of the glucagon response to hypoglycemia in adolescents with Type 1 diabetes. Diabetes Care 2012;35(8):1757-62. http://dx.doi.org/10.2337/dc11-2010

40. Dagogo-Jack SE, Craft S, Cryer PE. Hypoglycemia-associated autonomic failure in insulin-dependent diabetes mellitus. Recent antecedent hypoglycemia reduces autonomic responses to, symptoms of, and defense against subsequent hypoglycemia. J Clin Invest 1993;91:819-28. http://dx.doi.org/10.1172/JCI116302

41. Lorenzi M, Bohannon N, Tsalikian E, et al. Duration of type I diabetes affects glucagon and glucose responses to insulin-induced hypoglycemia. West J Med 1984;141:467-71.

42. Fukuda M, Tanaka A, Tahara Y, et al. Correlation between minimal secretory capacity of pancreatic beta-cells and stability of diabetic control. Diabetes 1988;37:81-8. http://dx.doi.org/10.2337/diab.37.1.81

43. Meier JJ, Gethmann A, Götze O, et al. Glucagon-like peptide 1 abolishes the postprandial rise in triglyceride concentrations and lowers levels of non-esterified fatty acids in humans. Diabetologia 2006;49:452-8. http://dx.doi.org/10.1007/s00125-005-0126-y

44. Varanasi A, Bellini N, Rawal D, et al. Liraglutide as additional treatment for type 1 diabetes. Eur J Endocrinol 2011;165:77-84. http://dx.doi.org/10.1530/EJE-11-0330

45. Kielgast U, Krarup T, Holst JJ, et al. Four weeks of treatment with liraglutide reduces insulin dose without loss of glycemic control in type 1 diabetic patients with and without residual beta-cell function. Diabetes Care 2011;34:1463-8. http://dx.doi.org/10.2337/dc11-0096

46. Raman VS, Mason KJ, Rodriguez LM, et al. The role of adjunctive exenatide therapy in pediatric type 1 diabetes. Diabetes Care 2010; 33:1294-6. http://dx.doi.org/10.2337/dc09-1959

47. Garg SK, Moser EG, Bode B, et al. Effect of Sitagliptin on post-prandial glucagon and GLP-1 levels in patients with type 1 diabetes: Investigator-initiated, double-blind, randomized, placebo-controlled trial. Endocr Pract 2012;:1-30.

48. Farngren J, Persson M, Schweizer A, et al. Vildagliptin reduces glucagon during hyperglycemia and sustains glucagon counterregulation during hypoglycemia in Type 1 diabetes. J Clin Endocrinol Metab 2012;97:1-8. http://dx. doi.org/10.1210/jc.2012-2332

49. Ellis SL, Moser EG, Snell-Bergeon JK, et al. Effect of sitagliptin on glucose control in adult patients with Type 1 diabetes: a pilot, double-blind, randomized, crossover trial. Diabet Med 2011;28:1176-81. http://dx.doi.org/10.1111/j.1464-5491.2011.03331.x

50. Foley JE, Ligueros-Saylan M, He Y-L, et al. Effect of vildagliptin on glucagon concentration during meals in patients with type 1 diabetes. Horm Metab Res 2008;40:727-30. http://dx.doi.org/10.1055/s-2008-1078754

51. Chase HP, Lutz K, Pencek R, et al. Pramlintide lowered glucose excursions and was well-tolerated in adolescents with type 1 diabetes: results from a randomized, single-blind, placebo-controlled, crossover study. J Pediatr 2009;155:369-73. http://dx.doi.org/10.1016/j.jpeds.2009.03.012
52. Edelman S, Garg S, Frias J, et al. A double-blind, placebo-controlled trial assessing pramlintide treatment in the setting of intensive insulin therapy in type 1 diabetes. Diabetes Care 2006;29:2189-95. http://dx.doi.org/10.2337/dc06-0042

53. Ratner RE, Dickey R, Fineman $M$, et al. Amylin replacement with pramlintide as an adjunct to insulin therapy improves long-term glycaemic and weight control in Type 1 diabetes mellitus: a 1-year, randomized controlled trial. Diabet Med 2004:21:1204-12. http://dx.doi.org/10.1111/j.1464-5491.2004.01319.x

54. Levetan C, Want LL, Weyer C, et al. Impact of pramlintide on glucose fluctuations and postprandial glucose, glucagon, and triglyceride excursions among patients with type 1 diabetes intensively treated with insulin pumps. Diabetes Care 2003:26:1-8. http://dx.doi.org/10.2337/diacare.26.1.1

55 Whitehouse F, Kruger DF, Fineman $\mathrm{M}$, et al. A randomized study and open-label extension evaluating the long-term efficacy of pramlintide as an adjunct to insulin therapy in type 1 diabetes. Diabetes Care 2002;25:724-30. http://dx.doi.org/10.2337/diacare.25.4.724

56. Flatt PR, Swanston-Flatt SK, Bailey CJ. Glucagon antiserum: a tool to investigate the role of circulating glucagon in obese-hyperglycaemic (ob/ob) mice. Biochem Soc Trans 1979;7:911-13.

57. Yan H, Gu W, Yang J, et al. Fully human monoclonal antibodies antagonizing the glucagon receptor improve glucose homeostasis in mice and monkeys. J Pharmacol Exp Ther 2009;329:102-11. http://dx.doi.org/10.1124/jpet.108.147009

58. Gu W, Yan H, Winters KA, et al. Long-term inhibition of the glucagon receptor with a monoclonal antibody in mice causes sustained improvement in glycemic control, with reversible alpha-cell hyperplasia and hyperglucagonemia. J Pharmacol Exp Ther 2009;331:871-81. http://dx.doi.org/10.1124/jpet.109.157685

59. Engel SS, Xu L, Andryuk PJ, Davies MJ, Amatruda J, Kaufman K GB. Efficacy and tolerability of MK-0893, a glucagon receptor antagonist, in patients with type 2 diabetes. Diabetes 2011;60:A85

60. Kelly RP, Garhyan P, Abu-Raddad EJ, Fu H, Lim CN, Prince MJ, Pinaire JA, Loh MT DM. Short-term treatment with glucagon receptor antagonist LY2409021 effectively reduces fasting blood glucose and HbA1c in patients with type 2 diabetes mellitus. Diabetes 2011;60:A84.

61. Ali S, Drucker DJ. Benefits and limitations of reducing glucagon action for the treatment of type 2 diabetes. Am J Physiol Endocrinol Metab 2009;296:E415-21. http://dx.doi.org/10.1152/ajpendo.90887.2008

62. Claus TH, Pan CQ, Buxton JM, et al. Dual-acting peptide with prolonged glucagon-like peptide-1 receptor agonist and glucagon receptor antagonist activity for the treatment of type 2 diabetes. J Endocrinol 2007;192:371-80. http://dx.doi.org/10.1677/JOE-06-0018

63. Fortin J-P, Chinnapen D, Beinborn $M$, et al. Discovery of dual-action membrane-anchored modulators of incretin receptors. PLOS One 2011;6:e24693. http://dx.doi.org/10.1371/journal.pone.0024693

64. Bhat VK, Kerr BD, Flatt PR, et al. A novel GIP-oxyntomodulin hybrid peptide acting through GIP, glucagon and GLP-1 receptors exhibits weight reducing and anti-diabetic properties. Biochem Pharmacol 2013; 85:1655-62. http://dx.doi.org/10.1016/j.bcp.2013.03.009

65. Nass R, Gaylinn BD, Thorner MO. The ghrelin axis in disease: potential therapeutic indications. Mol Cell Endocrinol 2011;340:106-10. http://dx.doi.org/10.1016/j.mce.2011.02.010

66. Denroche HC, Levi J, Wideman RD, et al. Leptin therapy reverses hyperglycemia in mice with streptozotocin-induced diabetes, independent of hepatic leptin signaling. Diabetes 2011:60:1414-23. http://dx.doi.org/10.2337/db10-0958

67. Garg A. Effects of metreleptin in Type 1 diabetes mellitus clinicaltrials.gov. 2010;:NCT01268644.

68. Ansarullah, Lu $Y$, Holstein $M$, et al. Stimulating $\beta$-cell regeneration by combining a GPR119 agonist with a DPP-IV inhibitor. PLOS One 2013;8:e53345. http://dx.doi.org/10.1371/journal.pone.0053345

69. Ogata A, Morishima A, Hirano T, et al. Improvement of HbA1c during treatment with humanised anti-interleukin 6 receptor antibody, tocilizumab. Ann Rheum Dis 2011;70:1164-5.

http://dx.doi.org/10.1136/ard.2010.132845 